\title{
Does concentration influence viability of the bronchial epithelial cell line chronically exposed to antiasthmatic drugs?
}

\author{
Dominika Oleś ${ }^{1}$, Aleksandra Szczepankiewicz'1 Maria Wołuń-Cholewa², Wanda Butowska², Paulina Sobkowiak ${ }^{3}$, \\ Zdzisława Kycler ${ }^{3}$, Jerzy Warchoł², Anna Bręborowicz ${ }^{3}$ \\ ${ }^{1}$ Laboratory of Molecular and Cell Biology, Poznan University of Medical Sciences, Poland \\ Head: Aleksandra Szczepankiewicz MD, PhD \\ 2Department of Cell Biology, Poznan University of Medical Sciences, Poland \\ Head: Małgorzata Katowicka MD, PhD \\ ${ }^{3}$ Department of Pediatric Pulmonology, Allergy and Clinical Immunology, Poznan University of Medical Sciences, Poland \\ Head: Prof. Anna Bręborowicz MD, PhD
}

Postep Derm Alergol 2012; XXIX, 5: 363-368

DOI: 10.5114/pdia.2012.31489

\begin{abstract}
Introduction: Bronchial epithelial cell lines enable analysis of influence of different factors, such as exposure to inhaled antiasthmatic agents, on their morphology and function in vitro.

Aim: To investigate whether chronic exposure to different concentrations of therapeutic agents used in the inhalation therapy of asthma influence bronchial epithelial cells growth and morphology.

Material and methods: Bronchial epithelial cell line 16HBE140- was used. We analyzed changes in viability between cells treated with different drug concentrations: budesonide, fluticasone propionate, salbutamol and ipratropium bromide. Observations were performed every $24 \mathrm{~h}$ for 4 days. Cells viability was analyzed by fluorescent staining and XTT assay.

Results: An inverse correlation between drug concentration and cells viability was observed. The only exception was ipratropium bromide which was toxic at all studied concentrations. Steroids at the two highest concentrations led to a significant decrease in cells viability with fluticasone propionate being more potent than budesonide. Incubation with salbutamol also demonstrated decreased cells viability at the two highest concentrations. Ipratropium bromide was toxic for the bronchial cells at all concentrations leading to a significant decrease in cells viability. Conclusions: Chronic exposure to the highest concentrations of steroids or $\beta_{2}$-agonists decreases viability of epithelial cells, whereas ipratropium bromide has the strongest influence on cell viability regardless of its concentration.

Key words: bronchial epithelial cells, bronchodilators, drug concentration, viability, steroids.
\end{abstract}

\section{Introduction}

Asthma is the most common chronic respiratory disease in the pediatric population [1]. According to the current guidelines, chronic treatment of asthmatic patients is strongly recommended. However, the main problem in pediatric patients with asthma involves possible side effects that may appear after chronic treatment with antiinflammatory agents (inhaled steroids) and bronchodilators ( $\beta_{2}$-agonists and anticholinergic agents). Both groups of drugs are administered directly to the airways via inhalation of drug aerosols that provides the most efficient and safest method of drug delivery. Therefore, the epithelial cell layer, which is the first barrier that protects the underlying airways from the environmental influences, is directly exposed to the drugs.

It has been reported that airway epithelium plays an important role in the asthma pathogenesis. Bronchial biopsies performed in moderate and severe asthmatic patients show epithelial damage and metaplasia, thickening of the subepithelial basal lamina and an increased number of myofibroblasts [2, 3]. Those observations 
together with the other characteristics of airway remodeling were found not only in severe chronic asthma cases, but also in the airways of pediatric patients in relation to the disease onset [4-6]. Airway epithelium is chronically injured and unable to repair properly in asthmatic patients $[7,8]$ and the epithelial cell layer is more fragile due to the disruption of tight junctions and desmosomes $[6,9]$. This results in the increased permeability, making airways more accessible to inhaled allergens, pollutants and other irritants (e.g. drug particles) [10].

The culture of epithelial cell layers to model the epithelia of the airway has undergone significant development for the last 10 years [11]. The 16HBE140- cell line has been used in drug permeability and transport studies and it was reported that cells permeability correlates with the absorption coefficients observed in the isolated perfused rat lung [12]. The cells possess a columnar phenotype with apical microvilli and form functional tight junctions [13-16]. All these features support the use of this cell line in the analysis of changes in the morphology and physiology of airway epithelium chronically exposed to antiasthmatic drugs [1].

Commercially available anti-inflammatory and bronchodilatatory drugs are widely used in the treatment of asthma, however, their effects on viability and morphology of the airway epithelial cells have not been fully understood.

\section{Aim}

We aimed to investigate the effects of drugs routinely used in the asthma treatment on the bronchial epithelium in vitro under chronic exposure to different concentrations of drug solutions [17].

\section{Material and methods \\ Chemicals and reagents}

Fluticasone propionate and salbutamol were purchased from GlaxoSmithKline (Poland), budesonide from Astra Zeneca (Poland) and ipratropium bromide from Boehringer Ingelheim (Poland). Minimal Essential Medium (MEM), 10\% Fetal Bovine Serum (FBS), L-glutamine, antibiotics (penicillin and streptomycin), Hanks' balanced salt solution (HBSS), trypsin were purchased from Sigma (Poznan, Poland). LHC (Lechner and Laveck Medium) basal medium was purchased from Invitrogen; Bovine Serum Albumin (BSA), bovine collagen I and human fibronectin were purchased from BD Biosciences. Cell culture supports (flasks, Petri dishes, 6-well plates) were purchased from BD Falcon.

\section{Cell culture}

The simian virus (SV) 40-transformed bronchial epithelial cell line 16HBE140- was purchased from Dieter C. Gruenert (California Pacific Medical Center, San Francis-
CO, USA). Cell stocks were grown in monolayer in 25 and $75 \mathrm{~cm}^{2}$ flasks in Minimal Essential Medium (MEM) supplemented with $10 \%$ (v/v) fetal bovine serum (FBS), $2 \mathrm{mmol} / / \mathrm{L}$-glutamine and $100 \mathrm{U} / \mathrm{ml}$ penicillin and $100 \mu \mathrm{g} / \mathrm{ml}$ streptomycin. The cells were maintained at $37^{\circ} \mathrm{C}$ in a humidified atmosphere of $95 \%$ air: $5 \% \mathrm{CO}_{2}$ and subcultured weekly using 0.22\% EDTA/0.25\% trypsin. For the experiment, the cells were seeded at an initial density of $1.0 \times 10^{6}$ cells $/ 8.55 \mathrm{~cm}^{2}$ in total volume of $1 \mathrm{ml}$ (0.5 ml of MEM and $0.5 \mathrm{ml}$ of drug solution) on $35 \mathrm{~mm}$ Petri dishes/6-well plates coated with the mixture containing LHC basal medium, 0.1\% BSA $(1 \mathrm{mg} / \mathrm{ml})$, bovine collagen I $(3 \mathrm{mg} / \mathrm{ml})$ and human fibronectin $(1 \mathrm{mg} / \mathrm{ml})$.

\section{Study design}

We analyzed the influence of four drug solutions at different concentrations with the highest concentration being a half of the maximum dose recommended for the treatment of pediatric asthmatic patients according to GINA recommendations. The further concentrations were 2-fold serial dilutions of the highest concentration. The following drugs in four concentrations were analyzed: - budesonide (Astra Zeneca): $0.25 \mathrm{mg} / \mathrm{ml}\left(5.8 \times 10^{-5} \mathrm{M}\right)$, $0.125 \mathrm{mg} / \mathrm{ml}\left(2.9 \times 10^{-5} \mathrm{M}\right), 0.0675 \mathrm{mg} / \mathrm{ml}\left(0.45 \times 10^{-5} \mathrm{M}\right)$, $0.03375 \mathrm{mg} / \mathrm{ml}\left(0.72 \times 10^{-5} \mathrm{M}\right)$;

- fluticasone propionate (GlaxoSmithKline): $0.5 \mathrm{mg} / \mathrm{ml}$ $\left(1 \times 10^{-6} \mathrm{M}\right), 0.25 \mathrm{mg} / \mathrm{ml}\left(0.5 \times 10^{-6} \mathrm{M}\right), 0.125 \mathrm{mg} / \mathrm{ml}$ $\left(0.25 \times 10^{-6} \mathrm{M}\right), 0.0675 \mathrm{mg} / \mathrm{ml}\left(0.125 \times 10^{-6} \mathrm{M}\right)$;

- salbutamol (GlaxoSmithKline): $1 \mathrm{mg} / \mathrm{ml}\left(4.2 \times 10^{-3} \mathrm{M}\right)$, $0.5 \mathrm{mg} / \mathrm{ml}\left(2.1 \times 10^{-3} \mathrm{M}\right), 0.25 \mathrm{mg} / \mathrm{ml}\left(1.05 \times 10^{-3} \mathrm{M}\right)$, $0.125 \mathrm{mg} / \mathrm{ml}\left(0.52 \times 10^{-3} \mathrm{M}\right)$;

- ipratropium bromide (Boehringer Ingelheim): $0.125 \mathrm{mg} / \mathrm{ml}$ $\left(2.2 \times 10^{-4} \mathrm{M}\right), 0.0625 \mathrm{mg} / \mathrm{ml}\left(1.1 \times 10^{-4} \mathrm{M}\right), 0.03125 \mathrm{mg} / \mathrm{ml}$ $\left(1.1 \times 10^{-4} \mathrm{M}\right), 0.015625 \mathrm{mg} / \mathrm{ml}\left(0.28 \times 10^{-4} \mathrm{M}\right)$.

The control cells were cultured in the same manner in MEM with PBS instead of drug solution.

Cells were continuously exposed to the drugs that were added every $24 \mathrm{~h}$ during medium change. Observations of cells were performed every $24 \mathrm{~h}$ for 4 days and the viability test was performed after 4 days of incubation with different drugs or with PBS in the control cells. All experiments were done in 8 replicates.

\section{XTT viability test}

The viability of cells was analyzed using the XTT colorimetric test, based on dynamics of reduction of XTT pigment (tetrazoline-2,3-bis(2-methoxy-4-nitro-5-sulphophenyl)-2H-5-carboxyanilide) by the living cells and production of the colorful product. Intensity of the orange color formed in the reaction was measured at the wavelength of $450 \mathrm{~nm}$. The percentage of growth inhibition was calculated according to the following equation:

100 - (OD of drug treated cells - OD of medium alone/OD of untreated cells-OD medium alone $\times 100$ ), where OD is optical density. 


\section{Statistical analysis}

Statistical analysis of the results was done with a nonparametric method (Kruskal-Wallis test) with post-hoc Dunn's test using the Statistica ver.8 software (Statsoft, Krakow, Poland) and the demo version of GraphPad Instat3 software. Value of $p<0.05$ was considered to represent the threshold of significance. After adjusting the significance level for multiple comparisons using Bonferroni's correction, the corrected significance level was less than 0.008

\section{Fluorescence microscopy}

Morphological evaluation and viability of epithelial cells 4 days after exposure to drug solutions was done with fluorescent dyes (Hoechst 33342, propidium iodide) and analyzed with fluorescent microscope (Eclipse TE200 Nikon). Apoptotic cells were identified as brightly fluorescing Hoechst 33342 stained cells (blue staining) displaying shrinkage with condensed, segmented nuclei. The necrotic cells were identified by brightly fluorescent Hoechst stained nuclei independent of chromatin condensation, coupled with PI fluorescence (red staining).

\section{Ultrastructural analysis}

After $72 \mathrm{~h}$, cells allocated to ultrastructural analysis were fixed in situ directly in culture dishes with use of $2.5 \%$ glutaraldehyde in $0.1 \mathrm{~mol} / \mathrm{l}$ phosphate buffer $\mathrm{pH}$ 7.4. After that, cells were rinsed twice in phosphate buffer and the material was post-fixed for an hour in $1 \%$ of osmium tetroxide in phosphate buffer. After rinsing cells twice in phosphate buffer and distilled water, they were incubated for an hour with $0.5 \%$ uranyl acetate. After that, the material was washed once in distilled water and then dehydrated through a graded ethanol/HPMA series (Hydroxypropyl Methacrylate) and embedded in culture dishes with use of epon. Material prepared according to the above protocol was cut for ultrathin sections with use of Ultracut III microtome (Reichert) and stained with uranyl acetate and lead citrate. For ultrastructure examination, a transmission electron microscope JEM-100 S (Jeol, Japan) was used. All reagents and chemicals mentioned above were purchased from Sigma Aldrich.

\section{Calcium measurement}

Intracellular $\mathrm{Ca}^{2+}$ concentration in the cultured cells was performed with Fluo3 (Molecular Probes, USA) with use of LSM 510 confocal microscope (Zeiss, Germany).

\section{Results}

All the analyzed drugs in each concentration and its effect on epithelial cells viability was shown in Figure 1.

For the comparisons to the control cells, all drugs at each concentration were significantly different between the drug and the control cells. To test whether the differ- ences between drug concentrations were significant we performed multiple comparisons between each drug concentration and the results are given in Table 1.

Budesonide at the highest concentration $(0.25 \mathrm{mg} / \mathrm{ml})$ led to the evident decrease in cells viability; however, for the drug concentration of $0.125 \mathrm{mg} / \mathrm{ml}$ and lower we did not observe such changes. The cells viability was inversely correlated to the drug concentration and those changes were significant in comparisons between all the concentrations except the highest and the lowest concentrations (Figure 1 and Table 1).

Changes in cells viability exposed to fluticasone propionate at different concentrations were significant (Table 1 and Figure 1) and after correction for multiple testing, the significance was observed for the following comparisons: $0.5 \mathrm{mg} / \mathrm{ml}$ vs. $0.125 \mathrm{mg} / \mathrm{ml}, 0.5 \mathrm{mg} / \mathrm{ml}$ vs. $0.067 \mathrm{mg} / \mathrm{ml}, 0.25 \mathrm{mg} / \mathrm{ml}$ vs. $0.067 \mathrm{mg} / \mathrm{ml}$.

Incubation with salbutamol at different concentrations influenced cells viability at the concentrations of $1 \mathrm{mg} / \mathrm{ml}$ and $0.5 \mathrm{mg} / \mathrm{ml}$ (Table 1 and Figure 1) and the pattern of decreased viability with increasing concentration was similar to that observed for fluticasone propionate.

Cells exposed to ipratropium bromide showed an extremely high decrease in cells viability associated with necrosis and subsequent cells dissociation from the culture dish surface. The decreased cells viability was demonstrated for all concentrations with the highest concentration of $0.125 \mathrm{mg} / \mathrm{ml}$ being significantly more toxic in comparison to lower concentrations (Table 1 and Figure 1).

Ultrastructure of control cells and cells exposed to studied drug solutions did not differ significantly. However, in the case of cells exposed to salbutamol and fluticasone propionate, we observed alterations in cell junctions. In control cells, tight junctions with numerous desmosomes were observed, whereas cells exposed to drug solutions mentioned above lacked tight intercellular connections and we observed free spaces between the cells.

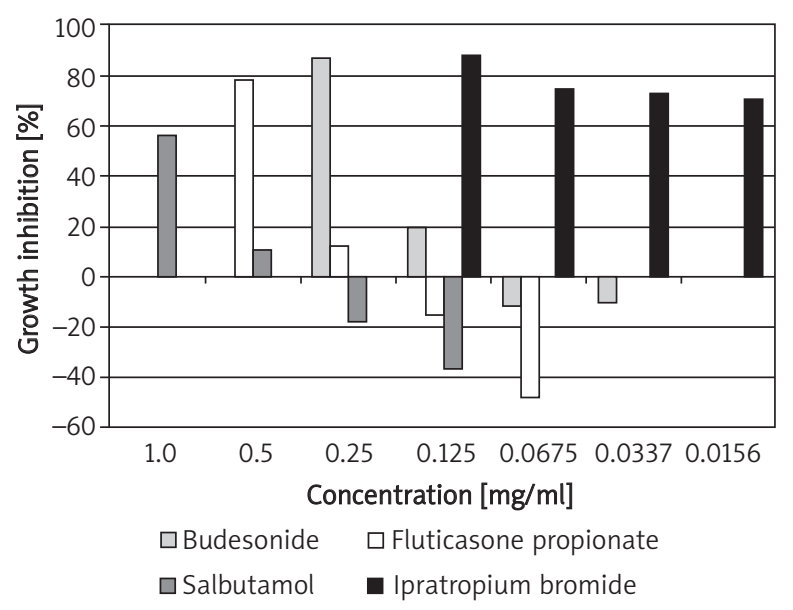

Figure 1. Growth inhibition of epithelial cells exposed to different antiasthmatic drugs 
Table 1. Multiple comparisons between different concentrations for each drug solution

\begin{tabular}{|c|c|c|}
\hline $\begin{array}{l}\text { Comparison between } \\
\text { concentrations }[\mathrm{mg} / \mathrm{ml}]\end{array}$ & $\begin{array}{l}\text { Mean rank } \\
\text { difference }\end{array}$ & Value of $p$ \\
\hline \multicolumn{3}{|l|}{ Budesonide } \\
\hline 0.25 vs. 0.125 & 32.0 & $<0.01$ \\
\hline 0.25 vs. 0.067 & 79.5 & $<0.001$ \\
\hline 0.25 vs. 0.034 & 80.5 & $<0.001$ \\
\hline 0.125 vs. 0.067 & 47.8 & $<0.001$ \\
\hline 0.125 vs. 0.034 & 48.5 & $<0.001$ \\
\hline 0.067 vs. 0.034 & 1.031 & $>0.05$ \\
\hline \multicolumn{3}{|l|}{ Fluticasone propionate } \\
\hline 0.5 vs. 0.25 & 32.0 & $<0.01$ \\
\hline 0.5 vs. 0.125 & 64.0 & $<0.001$ \\
\hline 0.5 vs. 0.067 & 96.0 & $<0.001$ \\
\hline 0.25 vs. 0.125 & 32.0 & $<0.01$ \\
\hline 0.25 vs. 0.067 & 64.0 & $<0.001$ \\
\hline 0.125 vs. 0.067 & 32.0 & $<0.01$ \\
\hline \multicolumn{3}{|l|}{ Salbutamol } \\
\hline 1 vs. 0.5 & 32.0 & $<0.01$ \\
\hline 1 vs. 0.25 & 64.0 & $<0.001$ \\
\hline 1 vs. 0.125 & 96.0 & $<0.001$ \\
\hline 0.5 vs. 0.25 & 32.0 & $<0.01$ \\
\hline 0.5 vs. 0.125 & 64.0 & $<0.001$ \\
\hline 0.25 vs. 0.125 & 32.0 & $<0.01$ \\
\hline \multicolumn{3}{|l|}{ Ipratropium bromide } \\
\hline 0.125 vs. 0.063 & 49.8 & $<0.001$ \\
\hline 0.125 vs. 0.032 & 51.7 & $<0.001$ \\
\hline 0.125 vs. 0.016 & 73.3 & $<0.001$ \\
\hline 0.063 vs. 0.032 & 1.0 & $>0.05$ (NS) \\
\hline 0.063 vs. 0.016 & 23.4 & $>0.05$ (NS) \\
\hline 0.032 vs. 0.016 & 21.6 & $>0.05$ (NS) \\
\hline
\end{tabular}

We also analyzed whether free calcium ions concentration in cultured cells may be altered due to exposure to different drug solutions. None of the analyzed drugs influenced free calcium ions concentration suggesting that this pathway may not be crucial for any of the drug action (data not shown).

\section{Discussion}

In our study we demonstrated that chronic exposure of bronchial epithelium to antiasthmatic drugs result- ed in decreased cell viability of exposed cells as compared to the control cells. Moreover, decreasing drug concentration positively correlated with cell viability, with higher concentrations significantly more toxic in comparison to lower doses. Interestingly, the most cytotoxic drug was ipratropium bromide regardless of its concentration.

Chronic exposure to steroids at two highest concentrations resulted in a decrease in cell viability; however, this decrease was reversible after drugs were removed from the cell culture. Our observations for epithelial cells under chronic exposure to steroids are in concordance with the analysis performed after inhalation of a single dose of beclomethasone that resulted in mild damage of bronchial epithelium and moderate damage of tracheal epithelium [18]. Moreover, in our study we observed that budesonide was significantly more toxic than fluticasone propionate. Comparing our results to the other studies performed in vitro, it was reported by Stellato et al. [19] that glucocorticoids might be inhibitors of the epithelial cell function (in the range of concentrations from $10^{-13} \mathrm{~mol} / / \mathrm{l}$ to $10^{-6} \mathrm{~mol} / \mathrm{l}$ ) with fluticasone propionate being more potent than budesonide to inhibit VCAM-1 expression. In their study it was also reported that epithelial cells are the most sensitive cells to steroids in comparison to the other cells such as eosinophils and basophils. The different outcome for steroids cytotoxicity in our results and the study by Stellato may result from the different time of exposure ( $24 \mathrm{~h}$ in the study by Stellato as compared to 4 days in our experiment) as well as from different drug concentrations and readout (VCAM-1 expression).

In several studies it was reported that salbutamol at the concentration of $1 \times 10^{-7} \mathrm{M}$ added to the human bronchial epithelial cell culture for $48 \mathrm{~h}$ was as potent as $10 \%$ serum in stimulating cell growth $[20,21]$. In contrast to the short-acting $\beta_{2}$-agonist salbutamol, a consistent pro-apoptotic effect was observed with the long-acting $\beta_{2}$-agonists, salmeterol and formoterol [22]. Our results demonstrated that chronic exposure (4 days) to salbutamol was associated with the decrease in cell viability for the two highest concentrations ( $1 \mathrm{mg} / \mathrm{ml}$ and $0.5 \mathrm{mg} / \mathrm{ml})$. One of the possible explanations of this discrepancy is that chronic exposure to $\beta_{2}$-adrenergic receptor agonists may affect cells proliferation via an increase in the CAMP level that may be responsible for G1 cell cycle arrest by inducing cyclin-dependent kinase inhibitor p27Kip1 [23]. Also, the CAMP increase contributes to downregulation of $\mathrm{Bcl}-2$ expression and acceleration of cell apoptosis in asthmatics [24].

To our knowledge, there are no studies analyzing the influence of ipratropium bromide on decreased viability of epithelial cells, therefore we cannot verify or discuss our results on chronic exposure of ipratropium bromide on decrease in cells viability, regardless of the drug concentration. 
The results regarding cells viability were obtained by two independent methods: fluorescent staining with Hoechst and propidium iodide and with use of colorimetric XTT test as a reference method. We also tried to apply flow cytometry in our analysis, however due to the presence of different cell subpopulations it was not possible to separate and count those cells.

As for research on respiratory epithelial permeability to drugs, a correlation between the in vitro model and in vivo conditions was observed [25]. However, the correlation between in vitro model and in vivo conditions in the cytotoxicity studies is significantly less obvious. Drug solutions at given concentrations in vitro have different concentrations and impact on epithelial cells in vivo where they are protected by several barriers, particularly the mucus layer rich in different protective substances and cells. Airway geometry, humidity, clearance mechanisms and presence of lung disease influence the drug deposition and therefore affect the therapeutic effectiveness of inhaled medications. Moreover, only $15-20 \%$ of the drug dose in the form of aerosol penetrates the lung, so the concentration of the drug targeting epithelial cells in vivo is lower than given in inhalation by both the bioavailability as well as limited inhalation efficiency. Therefore, our results may indicate only the need to undertake research on cytotoxicity of the inhaled drugs on respiratory epithelial cells, but for now it cannot be related directly to the clinical situation. Our study has been performed on the established cell line and requires verification in human bronchial primary epithelial cells before we can correlate our results to the in vivo situation.

\section{Conclusions}

In summary, despite different limitations of this study, our main observation that chronic exposure to lower drugs concentrations is generally less harmful for the epithelial cells, this finding can be considered as the treatment schedule is planned. However, these are preliminary results that need further confirmation before they can be used in clinical practice.

\section{Acknowledgments}

Dominika Oleś and Aleksandra Szczepankiewicz had an equal share in the preparation of this work. This study was supported by the Poznan University of Medical Sciences, grant no. 502-14-01105726-09185

\section{References}

1. Kasznia-Kocot J, Kowalska M, Górny RL, et al. Environmental risk factors for respiratory symptoms and childhood asthma. Ann Agric Environ Med 2010; 17: 221-9.

2. Knight DA, Holgate ST. The airway epithelium: structural and functional properties in health and disease. Respirology 2003; 8: $432-46$
3. Holgate ST, Holloway J, Wilson S, et al. Epithelial-mesenchymal communication in the pathogenesis of chronic asthma. Proc Am Thorac Soc 2004; 1: 93-8.

4. Fedorov IA, Wilson SJ, Davies DE, Holgate ST. Epithelial stress and structural remodelling in childhood asthma. Thorax 2005; 60: 389-94.

5. Saglani S, Malmstrom K, Pelkonen AS, et al. Airway remodeling and inflammation in symptomatic infants with reversible airflow obstruction. Am J Respir Crit Care Med 2005; 171: 722-7.

6. Barbato A, Turato G, Baraldo S, et al. Epithelial damage and angiogenesis in the airways of children with asthma. Am J Respir Crit Care Med 2006; 174: 975-81.

7. Bucchieri F, Puddicombe SM, Lordan JL, et al. Asthmatic bronchial epithelium is more susceptible to oxidant-induced apoptosis. Am J Respir Cell Mol Biol 2002; 27: 179-85.

8. Kicic A, Sutanto EN, Stevens PT, et al. Intrinsic biochemical and functional differences in bronchial epithelial cells of children with asthma. Am J Respir Crit Care Med 2006; 174: 1110-8.

9. Shahana S, Jaunmuktane Z, Asplund MS, Roomans GM. Ultrastructural investigation of epithelial damage in asthmatic and non-asthmatic nasal polyps. Respir Med 2006; 100: 2018-28.

10. Asman M, Solarz K, Szilman E, Szilman P. Analysis of expression and amino acid sequence of the allergen Mag 3 in two species of house dust mites-Dermatophagoides farinae and D. pteronyssinus (Acari: Astigmata: Pyroglyphidae). Ann Agric Environ Med 2010; 17: 45-8.

11. Sporty JL, Horalkova L, Ehrhardt C. In vitro cell culture models for the assessment of pulmonary drug disposition. Expert Opin Drug Metab Toxicol 2008; 4: 333-45.

12. Manford F, Tronde A, Jeppsson AB, et al. Drug permeability in 16HBE140- airway cell layers correlates with absorption from the isolated perfused rat lung. Eur J Pharm Sci 2005: 26: 414-20.

13. Ehrhardt C, Kneuer C, Fiegel J, et al. Influence of apical fluid volume on the development of functional intercellular junctions in the human epithelial cell line 16HBE140-: implications for the use of this cell line as an in vitro model for bronchia drug absorption studies. Cell Tissue Res 2002; 308: 391-400.

14. Ehrhardt C, Kneuer C, Laue M, et al. 16HBE14o- human bronchial epithelial cell layers express P-glycoprotein, lung resistance-related protein, and caveolin-1. Pharm Res 2003; 20: 545-51.

15. Forbes B, Shah A, Martin GP, Lansley AB. The human bronchial epithelial cell line 16HBE140- as a model system of the airways for studying drug transport. Int J Pharm 2003; 257: 161-7.

16. Winton HL, Wan H, Cannell MB, et al. Cell lines of pulmonary and non-pulmonary origin as tools to study the effects of house dust mite proteinases on the regulation of epithelial permeability. Clin Exp Allergy 1998; 28: 1273-85.

17. Karakis GP, Sin B, Tutkak H, et al. Genetic aspect of venom allergy: association with HLA class I and class II antigens. Ann Agric Environ Med 2010; 17: 119-23.

18. Uhlik J, Vajner L, Adaskova J, Konradova V. Effect of inhalation of single dose of beclomethasone on airway epithelium Ultrastruct Pathol 2007; 31: 221-32.

19. Stellato C, Atsuta J, Bickel CA, Schleimer RP. An in vitro comparison of commonly used topical glucocorticoid preparations. J Allergy Clin Immunol 1999; 104: 623-9. 
20. Nishimura K, Tamaoki J, Aoshiba K, et al. Effect of salbutamol on proliferation of human bronchial epithelial cells: role of MAP kinase. Nihon Kokyuki Gakkai Zasshi 1998; 36: 428-32.

21. Nishimura K, Tamaoki J, Isono K, et al. Beta-adrenergic receptor-mediated growth of human airway epithelial cell lines. Eur Respir J 2002; 20: 353-8.

22. Mamani-Matsuda M, Moynet D, Molimard M, et al. Longacting beta2-adrenergic formoterol and salmeterol induce the apoptosis of B-chronic lymphocytic leukaemia cells. $\mathrm{Br}$ J Haematol 2004; 124: 141-50.

23. Kato JY, Matsuoka M, Polyak K, et al. Cyclic AMP-induced G1 phase arrest mediated by an inhibitor (p27Kip1) of cyclindependent kinase 4 activation. Cell 1994; 79: 487-96.

24. Tai G, Eun-Young J, Yuji H, et al. Different effects of cyclic AMP and butyrate on eosinophilic differentiation, apoptosis and bcl-2 expression of a human eosinophilic leukemia cell line, EoL-1. Hematol Oncol 1996; 14: 181-92.

25. Mathia NR, Timoszyk J, Stetsko PI, et al. Permeability characteristics of calu-3 human bronchial epithelial cells: in vitroin vivo correlation to predict lung absorption in rats. J Drug Target 2002; 10: 31-40. 